\title{
IN-DEPTH SURVEY REPORT OF A DEMONSTRATION AND EVALUATION OF ROOFING TILE SAWS AND CUTTERS CONTROLLING RESPIRABLE AND CRYSTALLINE SILICA DUST
}

at

\section{Petersendean Roofing Systems Newark, California}

\author{
REPORT WRITTEN BY: \\ John W. Sheehy, PhD, PE, CIH \\ Alberto Garcia, MS \\ Alan Echt, MPH, CIH
}

REPORT DATE:

September 2006

REPORT NO:

EPHB 317-11a

\section{U.S. DEPARTMENT OF HEALTH AND HUMAN SERVICES}

Centers for Disease Control and Prevention

National Institute for Occupational Safety and Health

Division of Applied Research and Technology

Engineering and Physical Hazards Branch

4676 Columbia Parkway, Mail Stop R-5

Cincinnati, Ohio 45226-1998 
SITES SURVEYED:

SIC CODE:

SURVEY DATE:

SURVEY CONDUCTED BY:

EMPLOYER REPRESENTATIVES CONTACTED:

EMPLOYEE REPRESENTATIVES CONTACTED:
Petersendean Roofing Systems

Newark, California

1761

August 18-19, 2005

Alan Echt, NIOSH, Cincinnati, OH John Sheehy, NIOSH, Cincinnati, OH Alberto Garcia, NIOSH, Cincinnati, $\mathrm{OH}$

Jim Petersen, Petersendean Thomas Burke, Petersendean Doug Ziegler, Petersendean Mark Dickson, Aussieblue Roofing Chris Fisher, Hytile

John Barnhard, United Union of Roofers, Waterproofers and Allied Workers Pam Susi, Center to Protect Workers Rights Orlando Castellon, Roofers and Waterproofers L.U. 81, Oakland, CA 


\section{DISCLAIMER}

Mention of company names or products does not constitute endorsement by the Centers for Disease Control and Prevention.

The findings and conclusions in this report are those of the authors and do not necessarily represent the views of the National Institute for Occupational Safety and Health. 


\begin{abstract}
The objective of this study was to conduct a demonstration and evaluation of roofing tile saws and the Hytile tile cutter at the Petersendean Roofing Systems training site. The study was conducted over two days. On the first day an experienced tile roofer demonstrated the Hytile tile cutter by cutting flat and curved roof tiles and showed that roof tiles could be cut quickly and cleanly. Short-term sample results showed personal exposures with the Hytile would be below the OSHA silica construction standard. A Bosch electric-powered saw with local exhaust ventilation was also tested and a short-term personal sample while using the Bosch electric saw was just below the OSHA construction standard PEL. On the second day apprentice and journeyman roofers demonstrated four saws and the Hytile tile cutter for interested parties including representatives from the Center to Protect Worker Rights (CPWR), the United Union of Roofers, Waterproofers and Allied Workers, Petersendean Roofing Systems (including representatives from Petersendean facilities in Newark and Southern California, Nevada, and Arizona), and the local roofers union. The roofing saws demonstrated included the Bosch handheld electric-powered saw, the Partner gasoline-powered saw, the Revelation saw, and the Bronco water backpack saw. Short-term personal respirable dust and crystalline silica samples were collected on the roofers demonstrating the Hytile tile cutter and one of the saws. The airborne sampling data indicated that exposures when using the Hytile cutter, if extrapolated for a full shift, would have been below the OSHA PEL for silica, while the silica exposures using the Partner saw would have been several times the OSHA PEL. Real-time sampling results showed that the respirable dust exposure using the Hytile cutter were approximately two orders of magnitude lower than when using either the Partner gasoline-powered saw or the Bosch saw. The Real-time sampling results are based on short sampling periods of about four to five minutes.
\end{abstract}

Valuable input was provided by the observers at the demonstration. The use of the water backpack was found to be highly unfavorable because it was too heavy and water creates a slipping hazard on the roof. Material discoloration was also found to be an issue of the water suppression technique, since water provokes a staining on the concrete tiles. The Bosch 1364 was considered to be too heavy and was also considered cumbersome to use due to the addition of a 2" vacuum hose line from the roof to the vacuum cleaner. Most observers liked the Hytile and believed it could be used on the roof on valleys where smooth cuts are not required. Regular saws would still be needed for some cutting (e.g., for very smooth cuts). Virtually no visible dust was observed when cutting with the Hytile. One observer stated that the Hytile could be used for cutting about $40 \%$ of the roofing tiles while roofing a house-implying the remainder of the roof tiles would be cut using conventional methods. The Revelation saw brought to the demonstration was considered unacceptable by all the observers because the dust collector, to be effective, necessitating inactivating the blade guard. This demonstration study was very valuable in identifying directions for the NIOSH engineering control study for silica and respirable dust exposures in tile roofing construction. Specifically, the results showed: 1) cutters such as the Hytile appear to produce less dust and silica exposures than conventional saws; 2) the quality of the cuts must be smooth in any visible part of the roof; 3 ) the engineering control or work practice should not introduce an additional hazard such as falling or electrical hazard; and 
4) add-on controls such as LEV must not significantly increase the weight of the tool or add safety and ergonomic hazards for the worker. As a result, NIOSH researchers need to continue to collaborate with roofing tile manufacturers, tool manufacturers, contractors, and employee representatives to identify and test potentially effective control methods. 


\section{INTRODUCTION}

The National Institute for Occupational Safety and Health (NIOSH) is located in the Centers for Disease Control and Prevention (CDC), part of the Department of Health and Human Services (DHHS). NIOSH was established in 1970 by the Occupational Safety and Health Act, at the same time that the Occupational Safety and Health Administration (OSHA) was established in the Department of Labor (DOL). The OSH Act legislation mandated NIOSH to conduct research and education programs separate from the standard-setting and enforcement functions conducted by OSHA. An important area of NIOSH research deals with methods for controlling occupational exposure to potential chemical and physical hazards.

The Engineering and Physical Hazards Branch (EPHB) of the Division of Applied Research and Technology (DART) has been given the lead within NIOSH to study and develop engineering controls, and assess their impact on reducing occupational illness. Since 1976, EPHB (and its predecessor, the Engineering Control Technology Branch) has conducted a large number of studies to evaluate engineering control technology based upon industry, process, or control technique. The objective of each of these studies has been to evaluate and document control techniques and to determine their effectiveness in reducing potential health hazards in an industry or for a specific process.

The goal of this project is to evaluate and document the effectiveness of engineering controls in reducing respirable dust, silica exposures, and noise during tasks where roofers cut concrete roofing tiles. This aim can be evaluated in terms of the reduction in personal exposures of workers who operate the equipment when controls are used versus exposures when controls are not used. The long-term goal of this project is to reduce roofers' exposures to silica, respirable dust and noise while installing concrete tiles in roofing construction.

Based on the results of this study, the identification of successful dust control strategies, roofers will be able choose from among several effective controls identified through this study to control their exposures. Through a partnership among roofing contractors, the roofing unions, and other parties, controls identified as effective in this study will be adopted for use by roofers when they cut concrete tiles. The use of effective engineering controls will be enhanced by the production of best practice guidelines as well as model contract specifications, product literature, and apprentice training programs.

\section{Occupational Exposure to Crystalline Silica}

Silicosis is an occupational respiratory disease caused by inhaling respirable crystalline silica dust. Silicosis is irreversible, often progressive (even after exposure has ceased), and potentially fatal. Because no effective treatment exists for silicosis, prevention through exposure control is essential. Exposure to respirable crystalline silica dust occurs in many occupations, including construction. Crystalline silica refers to a group of minerals composed of silicon and oxygen; a crystalline structure is one in which the atoms are arranged in a repeating three-dimensional 
pattern. ${ }^{1}$ The three major forms of crystalline silica are quartz, cristobalite, and tridymite. ${ }^{1}$ Quartz is the most common form of crystalline silica. ${ }^{1}$ Respirable refers to that portion of airborne crystalline silica that is capable of entering the gas-exchange regions of the lungs if inhaled; this includes particles with aerodynamic diameters less than approximately $10 \mu \mathrm{m} .^{2}$

When proper practices are not followed or controls are not maintained, respirable crystalline silica exposures can exceed the NIOSH Recommended Exposure Limit (REL), the OSHA Permissible Exposure Limit (PEL), or the American Conference of Governmental Industrial Hygienists (ACGIH) Threshold Limit Value (TLV). ${ }^{2-4}$ NIOSH recommends an exposure limit of $0.05 \mathrm{mg} / \mathrm{m}^{3}$ to reduce the risk of developing silicosis, lung cancer, and other adverse health effects.

The OSHA PEL - General Industry Standard - for respirable dust containing 1\% quartz or more is expressed as an equation:

$$
\text { Respirable PEL }=\frac{10}{(\% \text { Silica })+2}
$$

If, for example, the dust contains no crystalline silica, the PEL is $5 \mathrm{mg} / \mathrm{m}^{3}$, and if the dust is $100 \%$ crystalline silica, the PEL is $0.1 \mathrm{mg} / \mathrm{m}^{3}$. The ACGIH TLV for quartz is $0.05 \mathrm{mg} / \mathrm{m}^{3}$.

The OSHA PEL - Construction Standard - for respirable dust containing 1\% quartz or more is expressed as an equation ${ }^{5}$ :

$$
\text { PEL }=\frac{250}{(\% \text { Silica })+5}
$$

The measured gravimetric exposure is converted using the NIOSH conversion factor $1 \mathrm{mppcf}=$ $0.1 \mathrm{mg} / \mathrm{m}^{3}$.

\section{METHODS}

\section{Description of saws and cutters}

The Hytile tile cutter uses a chisel-on-wheel system where a steel wheel scribes lines on the roof tile before the chisel breaks it. The cut is not as smooth as a powered hand saw, but should be acceptable especially where the edge is overlapped with another tile. The Hytile cutter is shown in Figure 1.

A Bosch hand-held electric-powered saw was equipped with a local exhaust hood connected by a 2 " flexible hose to a vacuum cleaner equipped with a HEPA filter as shown in Figure 2. 
The Partner gasoline-powered saw did not have any local exhaust ventilation on it. It was equipped with water spray nozzles that were not in use at the time of the evaluation.

The Revelation saw consisted of a Skill electric-powered saw with an aftermarket local exhaust ventilation installed. The local exhaust ventilation consisted of a shroud attached to the cutting plane of the saw; the shroud was then connected to a small electric axial fan, which is intended to collect dust at the point of generation. After passing through the fan, the dust was collected and retained on a cloth bag which also served as a filter media.

An electric-powered Partner saw was used in conjunction with the Bronco water backpack (Figure 3). The saw was equipped with water spray nozzles intended to control the dust generated when cutting concrete tiles. The use of water raised concerns among industry representatives about staining of roofing tiles.

The effectiveness of several of the roofing tile saws and the Hytile tile cutter at Petersendean Roofing Systems training site was assessed by observing the performance of each piece of equipment while cutting roofing tiles and collecting short-term personal samples for respirable dust and silica. The demonstration was conducted over one and half days. On the first day, an experienced tile roofer cut flat and curved roof tiles using alternately the Hytile tile cutter and a Bosch electric-powered saw while short term personal samples were collected.

On the second day tests were conducted on a mock-up roof. Two apprentice roofers and a journeyman roofer cut both flat and curved roofing tiles using the Hytile cutter and a Partner gasoline-powered saw. The observers (from CPWR, the United Union of Roofers, Waterproofers and Allied Workers, Petersendean Roofing Systems in Newark and Southern California, Nevada, and Arizona, and the local roofers union) considered three saws - the combination Partner Bronco water backpack saw, the Bosch 1364 hand-held electric powered saw, and the Revelation saw - unacceptable for actual use in cutting tiles on the roof so these saws were not tested. Use of the water backpack was found to be highly unfavorable because it was too heavy and water creates a slipping hazard on the roof. The Bosch 1364 was not tested on day two because it was considered to be too heavy and was also considered to be cumbersome to use due to the addition of a 2 " vacuum hose line from the roof to the vacuum cleaner. The Revelation saw was considered unacceptable by all the observers because the dust collector, to be effective, required the saw to be pulled by the worker towards himself, necessitating the removal of the blade guard thus defeating the guards purpose to protect the worker.

For the tools tested respirable dust and quartz samples were collected in the breathing zone of the worker when cutting roofing tiles. Samples were collected at a flow rate of 4.2 liters/minute (lpm) using a battery-operated sampling pump connected via Tygon tubing to a pre-weighed, 37 mm diameter, 5-micron $(\mu \mathrm{m})$ pore-size polyvinyl chloride filter supported by a backup pad in a three-piece filter cassette sealed with a cellulose shrink band in accordance with NIOSH Methods 0600 and 7500, and a cyclone (BGI4L Respirable/Thoracic Cyclone, BGI Inc., Waltham, MA). ${ }^{6}$ In addition, the worker wore a second battery-operated sampling pump operated a flow rate of $2.2 \mathrm{lpm}$. The flow passed through a real time portable laser photometer 
(MIE PDR DataRam pDR-1200 Particulate Monitor) connected via flexible tubing to a respirable dust pre-selector aluminum BGI4L cyclone) placed in the employee's breathing zone. Bulk samples of settled dust were also collected in accordance with NIOSH Method $7500 .^{6}$

Gravimetric analysis for respirable particulate was carried out with the following modifications to NIOSH Method 0600: 1) the filters and backup pads were stored in an environmentally controlled room $\left(20^{\circ} \pm 1^{\circ} \mathrm{C}\right.$ and $50 \pm 5 \%$ relative humidity) and were subjected to the room conditions for at least two hours for stabilization prior to tare and gross weighing, and, 2) two weighings of the tare weight and gross weight were performed. ${ }^{6}$ The difference between the average gross weight and the average tare weight was the result of the analysis. The limit of detection for this method was $0.02 \mathrm{mg}$.

Crystalline silica analysis of filter and bulk samples was performed using X-ray diffraction. NIOSH Method 7500 ( $4^{\text {th }}$ Ed.) was used with the following modifications: 1) filters were dissolved in tetrahydrofuran rather than being ashed in a furnace; and 2) standards and samples were run concurrently and an external calibration curve was prepared from the integrated intensities rather than using the suggested normalization procedure. ${ }^{6}$ These samples were analyzed for quartz. The limit of detection for quartz on filters was $0.01 \mathrm{mg}$. The limit of quantitation is $0.03 \mathrm{mg}$. The limit of detection and limit of quantification in the bulk sample for quartz was $0.8 \%$ and $2 \%$, respectively.

\section{Wind and weather measurements}

Wind direction and velocity were measured using an ultrasonic wind sensor (Wind Observer II, Gill Instruments Ltd., Lymington, England) mounted on a low wooden stand and placed on top of a stack of stored construction material. Temperature and relative humidity were obtained from the Oakland, California National Weather Service office for August $18^{\text {th }}$ and $19^{\text {th }}$.

\section{RESULTS AND DISCUSSION}

The results for this demonstration and evaluation of roofing tile saws and a tile cutter consisted of short-term personal filter sampling respirable dust and silica exposures, direct reading dust concentrations and observations by representatives of tile manufactures, construction trade unions and tile roofers.

\section{$\underline{\text { Respirable Crystalline Silica and Respirable Dust Exposures }}$}

The results of short-term personal breathing zone samples collected using the filters and cyclones are presented in Appendix Table A-1 and summarized in Table 1. Respirable dust results using the Hytile cutter ranged from less than $0.6 \mathrm{mg} / \mathrm{m}^{3}(5.7 \mathrm{mppcf})$ to less than $0.7 \mathrm{mg} / \mathrm{m}^{3}(7.0$ mppcf). Respirable dust results while using the gasoline-powered Partner saw without LEV ranged from less than $1.6 \mathrm{mg} / \mathrm{m}^{3}$ (16 mppcf) to $5.4 \mathrm{mg} / \mathrm{m}^{3}$ (54 mppcf). The data indicate that exposures using the Hytile cutter, if extrapolated for a full shift, would be below the OSHA PEL 
for silica, while the silica exposures using the Partner saw would have been several times the OSHA PEL. (A single short-term personal sample collected while using the Bosch electric saw was less than $\left.1.1 \mathrm{mg} / \mathrm{m}^{3}(<11 \mathrm{mppcf})\right)$.

Personal sample silica quartz concentrations were all below the limit of detection except for three samples taken while using the Partner Saw (without LEV). These silica quartz exposures were between the limit of detection and limit of quantitation and ranged from 0.41 to $0.45 \mathrm{mg} / \mathrm{m}^{3}$. Results in this range are semi-quantitative estimates. The NIOSH REL for silica quartz is 0.05 $\mathrm{mg} / \mathrm{m}^{3}$. This small data set indicates that using a gasoline powered saw to cut roof tiles would probably result in respirable dust and crystalline silica concentrations above the occupational exposure limits (OELs).

\section{$\underline{\text { Real Time (Direct Reading) }}$}

The direct-reading sampling results for day one sampling show that the average respirable dust (relative) exposure was $0.014 \mathrm{mg} / \mathrm{m}^{3}$ with the Hytile cutter and $2.5 \mathrm{mg} / \mathrm{m}^{3}$ using the Bosch saw. Thus, the average direct reading dust exposure with the Hytile was less than one-hundredth that when using the powered saw. The roofer, with previous experience using the Hytile tile cutter, cut flat and curved roof tiles first with the Hytile and then with the Bosch saw on day one. Sampling times were 5 min $13 \mathrm{sec}$ with the Hytile and $2 \mathrm{~min} 55 \mathrm{sec}$ with the Bosch. Figure 4 compares the direct reading results using the Hytile cutter with the Bosch saw over a 175 seconds sampling period. While using the Bosch saw the roofer stopped sawing during the last 30 seconds which is reflected in the near zero dust exposures from 145 to 175 seconds.

On day two, seven direct reading runs were conducted: four using the Hytile and three with the gasoline-powered Partner saw. The results are shown in Table 2 and Figures 5 and 6 . The average dust concentration was $6.5 \mathrm{mg} / \mathrm{m}^{3}$ for the gas powered Partner saw and $0.08 \mathrm{mg} / \mathrm{m}^{3}$ with the Hytile Cutter or almost two orders of magnitude higher for the Partner saw. In Figure 5 the Hytile respirable dust exposures (blue line) were near zero while those for the Partner saw showed peaks exceeding $30 \mathrm{mg} / \mathrm{m}^{3}$. Figure 6 presents the same results as Figure 5 but on a log scale. Although based on limited sampling data, these Real-time sampling results show the Hytile has the potential to substantially reduce dust (and silica) exposures compared to the powered saws. Real-time sampling results were in line with the personal sampling results; however, the sampling times for the personal respirable dust samples were not long enough to quantify the much lower respirable dust exposures for the Hytile compared to the Partner saw.

\section{Observations}

Valuable input was provided by the observers at the demonstration. The use of water was found to be highly unfavorable because the workers considered the backpack to be too heavy and water creates a slipping hazard on the roof. The Bosch 1364 equipped with a LEV was also considered to be too heavy. The gasoline powered Partner saw was considered acceptable and required no electric hook-up. Most observers liked the Hytile and believed it could be used on the roof. Regular saws would still be needed for some cutting (e.g., for very smooth cuts). Virtually no 
visible dust was observed when cutting with the Hytile. One observer stated that the Hytile could be used for cutting about $40 \%$ of the roofing tiles while roofing a house-implying that the remainder of the roof tiles would be cut using conventional methods. No one had a favorable impression of the LEV equipped Revelation saw brought to the demonstration.

This demonstration study was very valuable in identifying the directions for the NIOSH engineering control study for reducing silica and respirable dust exposures in tile roofing. The major observations are: 1) cutters such as the Hytile appear to produce less dust and silica exposures than conventional saws; 2 ) the quality of the cuts must be smooth in any visible part of the roof and in some high end work nearly all cuts must be smooth; 3) any recommended engineering control or work practice should not introduce an additional hazard such as a fall or electrical hazard; and 4) add-on controls such as LEV must not significantly increase the weight of the tool or add safety and ergonomic hazards for the worker. These findings show NIOSH researchers need to identify the types of equipment (saws, cutters, etc.) that the roofing industry considers reasonable to use and work with contractors to test potentially effective controls during actual housing construction. This will require continued collaboration with roofing tile manufactures, tool manufactures, contractors, and employee representatives to identify and test potentially effective control methods.

\section{Bulk Crystalline Silica Sampling Results}

The bulk sample contained $17 \%$ quartz (by weight). The limit of quantification for quartz was $2 \%$.

\section{Wind and Weather Results}

The average wind speed was $1.4 \mathrm{mph}$, with a maximum of $3.6 \mathrm{mph}$. The prevailing wind was from the northwest (average bearing 281 degrees). No attempt was made to correlate wind speed with exposure. However, based on observations of the airborne dust, the wind did not appear to hinder the effectiveness of the controls nor do much to clear away the airborne dust. The temperature ranged from $65^{\circ} \mathrm{F}$ to $66^{\circ} \mathrm{F}$ on $8 / 18 / 05$ and from $58^{\circ} \mathrm{F}$ to $63^{\circ} \mathrm{F}$ on $8 / 19 / 05$. The dew point was $55^{\circ} \mathrm{F}$ and $54^{\circ} \mathrm{F}$ on $8 / 18 / 05$ and $8 / 19 / 05$, respectively.

\section{CONCLUSIONS AND RECOMMENDATIONS}

This study demonstrated that roof tile cutters such as the Hytile appear to produce less respirable dust and silica exposures than conventional saws with no control or with add-on LEV controls. The Bosch saw with add-on LEV did not appear to adequately reduce respirable dust exposures, based on very limited sampling data. The study also showed that:

- An experienced tile roofer could cut roofing tiles quickly and cleanly with the Hytile cutter. Virtually no visible dust was observed when cutting with the Hytile and real-time and short-term personal exposure results showed the Hytile cutter produced much less 
respirable dust than conventional saws. One observer stated that the Hytile could be used for cutting about $40 \%$ of the roofing tiles while roofing a house-implying the remainder of the roof tiles would need to be cut using conventional saws. The major concern about the Hytile cutter is that the quality of the cuts may not be as smooth as required for certain roofing applications. A secondary concern was the possibility of reduced productivity when using a tile cutter instead of a powered saw.

- The electric-powered Partner saw used in conjunction with the Bronco water backpack was deemed to be unusable in actual roofing tile construction. The use of the water backpack was found to be highly unfavorable because it was too heavy and water creates a slipping hazard on the roof. Material discoloration was also found to be an issue of the water suppression technique, since water stains the concrete tiles.

- The Bosch 1364 was considered to be too heavy and was also cumbersome due to the addition of a 2" vacuum hose line from the roof to the vacuum cleaner.

- The Revelation saw brought to the demonstration was considered unacceptable by all the observers because the dust collector, to be effective, necessitating the removal of the blade guard.

This demonstration study at Petersendean contributed significantly to the understanding and planning of the overall NIOSH engineering research study for controlling respirable dust and silica exposures in tile roofing construction industry. First, field surveys to evaluate the performance and effectiveness of mechanical tile cutters such as the Hytile should be conducted during actual roofing construction. These in-depth surveys should include measuring full-shift and short-term personal breathing zone concentrations of respirable particulate and crystalline silica and real-time sampling. Besides ventilated saws with LEV and mechanical cutters, there is a need to identify additional engineering control techniques and work practices that are practical and may effectively reduce exposures to crystalline silica and airborne dust below Occupational Exposure Limits in roofing tile cutting operations. NIOSH researchers need to follow-up with key partners including roofing tile manufactures, tool manufactures, contractors, and employee representatives to identify additional potentially effective control methods and to locate tile roofing construction sites where the control methods can be tested. The option of using water as a dust suppressant has a number of draw backs; however, it should not be ruled out as a potential control technology and should be studied further. 


\section{REFERENCES}

1. Bureau of Mines [1992]. Crystalline silica primer. Washington, DC: U.S. Department of the Interior, Bureau of Mines, Branch of Industrial Minerals, Special Publication.

2. NIOSH [2002]. NIOSH Hazard Review: Health Effects of Occupational Exposure to Respirable Crystalline Silica. Cincinnati, OH: U.S. Department of Health and Human Services, Public Health Service, Centers for Disease Control and Prevention, National Institute for Occupational Safety and Health, DHHS (NIOSH) Publication No. 2002-129.

3. 29 CFR 1910.1000 [2001]. Occupational Safety and Health Administration: air contaminants.

4. ACGIH [2001]. Threshold limit values for chemical substances. Cincinnati, OH: American Conference of Governmental Industrial Hygienists

5. OSHA [2001] Memorandum for: regional administrators and silica coordinators from: Richard E. Fairfax Director, Directorate of Compliance Programs. Subject: transmission of NIOSH recommended conversion factor for silica sample results and favorable appellate court decision on silica sampling. September 4, 2001.

6. NIOSH [1994]. NIOSH manual of analytical methods. 4th rev. ed., Eller PM, Ed. Cincinnati, OH: U.S. Department of Health and Human Services, Public Health Service, Centers for Disease Control and Prevention, National Institute for Occupational Safety and Health, DHHS (NIOSH) Publication No. 94-113. 


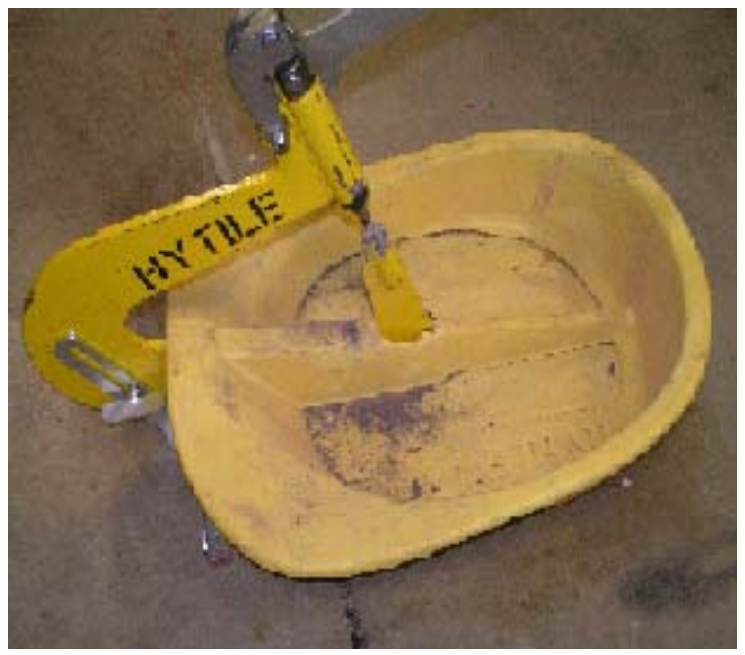

Figure 1: Hytile Cutter

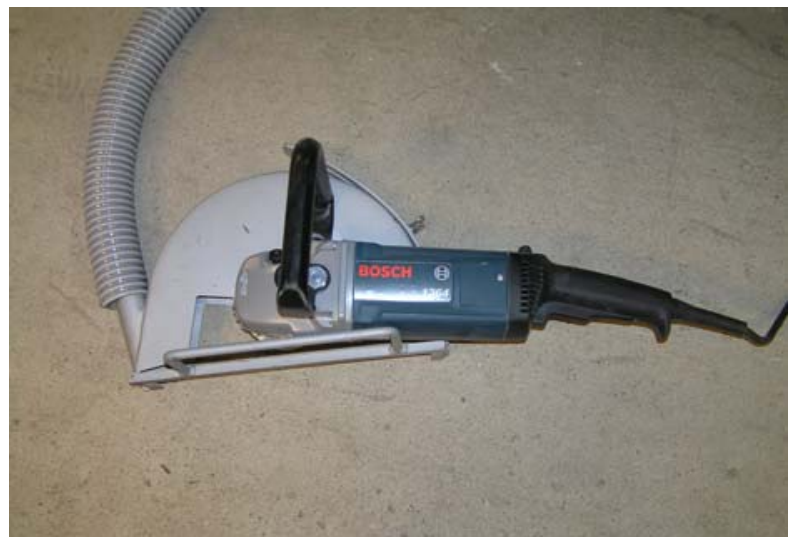

Figure 2: Bosch Hand-held Electric-powered Saw 


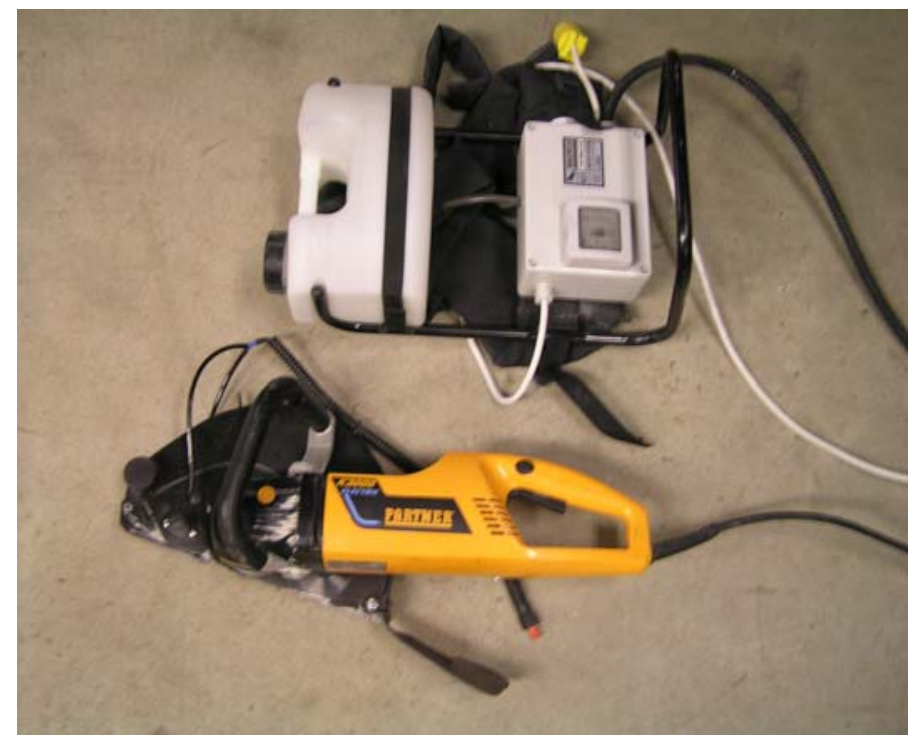

Figure 3: Partner Saw with Bronco Water Backpack 
Table 1. Respirable Dust Concentrations Compared to Silica Quartz Standard

\begin{tabular}{|l|c|c|c|c|}
\hline \multicolumn{1}{|c|}{ Saw/Cutter } & $\begin{array}{c}\text { Number of } \\
\text { Samples }\end{array}$ & $\begin{array}{c}\text { Average } \\
\text { Concentration } \\
\mathrm{mg} / \mathrm{m} 3\end{array}$ & $\begin{array}{c}\text { Concentration } \\
\text { Range } \\
\mathrm{mg} / \mathrm{m} 3\end{array}$ & $\begin{array}{c}\text { Average } \\
\text { Concentration } \\
\mathrm{mppcf}\end{array}$ \\
\hline Hytile & 7 & $<0.6$ & $<0.6-<0.7$ & $<6.2$ \\
\hline Partner Gasoline & 5 & 3.5 & $<1.6-5.4$ & 35 \\
\hline Bosch & 1 & $<1.1$ & - & $<11$ \\
\hline $\begin{array}{l}\text { OSHA General } \\
\text { Industry Standard } \\
\text { Quartz }\end{array}$ & & $\begin{array}{c}0.53 \\
\text { based on } \\
17 \% \text { silica) }\end{array}$ & & 11.4 \\
\hline $\begin{array}{l}\text { OSHA } \\
\text { Construction } \\
\text { Standard Quartz }\end{array}$ & & & & \\
\hline
\end{tabular}


Table 2: Direct Reading Respirable Dust Results

\begin{tabular}{|c|c|c|c|c|c|c|}
\hline Trials & Saw or Cutter & $\begin{array}{c}\text { Shape } \\
\text { of Tile }\end{array}$ & N Obs. & $\begin{array}{c}\text { Sample } \\
\text { Time } \\
\text { min:sec }\end{array}$ & $\begin{array}{c}\text { Arithmetic } \\
\text { Mean } \\
\mathrm{mg} / \mathrm{m}^{3}\end{array}$ & $\begin{array}{c}\text { Max } \\
\text { STEL } \\
\mathrm{mg} / \mathrm{m}^{3} \\
\end{array}$ \\
\hline \multicolumn{7}{|c|}{$\begin{array}{l}\text { DAY } 1 \\
\end{array}$} \\
\hline 1 & Hytile & & 313 & 5:13 & 0.014 & 0.005 \\
\hline 2 & Bosch & & 175 & $2: 55$ & 2.51 & 0.48 \\
\hline \multicolumn{7}{|c|}{ DAY 2} \\
\hline 1 & Hytile & curved & 329 & $5: 29$ & 0.028 & 0.01 \\
\hline 2 & Hytile & flat & 330 & $5: 30$ & 0.053 & 0.02 \\
\hline 3 & $\begin{array}{c}\text { Gasoline } \\
\text { Partner Saw }\end{array}$ & curved & 347 & $5: 47$ & 4.80 & 1.85 \\
\hline 4 & $\begin{array}{c}\text { Gasoline } \\
\text { Partner Saw }\end{array}$ & flat & 330 & $5: 30$ & 8.20 & 3.00 \\
\hline 5 & Hytile & flat & 328 & $5: 28$ & 0.12 & 0.039 \\
\hline 6 & Hytile & flat & 318 & $5: 18$ & 0.12 & 0.039 \\
\hline 7 & $\begin{array}{c}\text { Gasoline } \\
\text { Partner Saw }\end{array}$ & flat & 252 & $4: 12$ & 6.38 & 1.78 \\
\hline
\end{tabular}




\section{Direct Reading Dust Concentration}

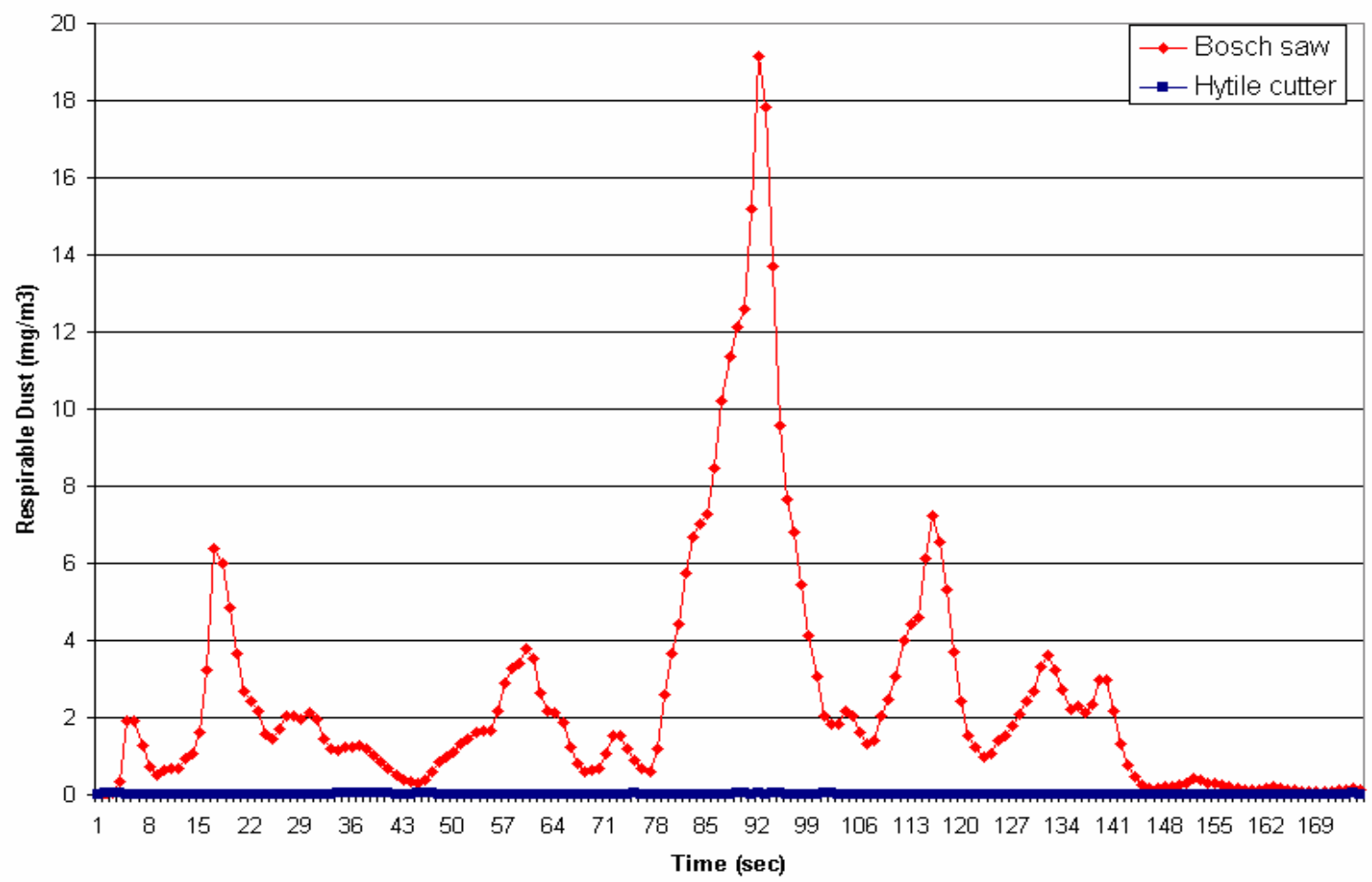

Figure 4. Bosch Saw versus Hytile Cutter 


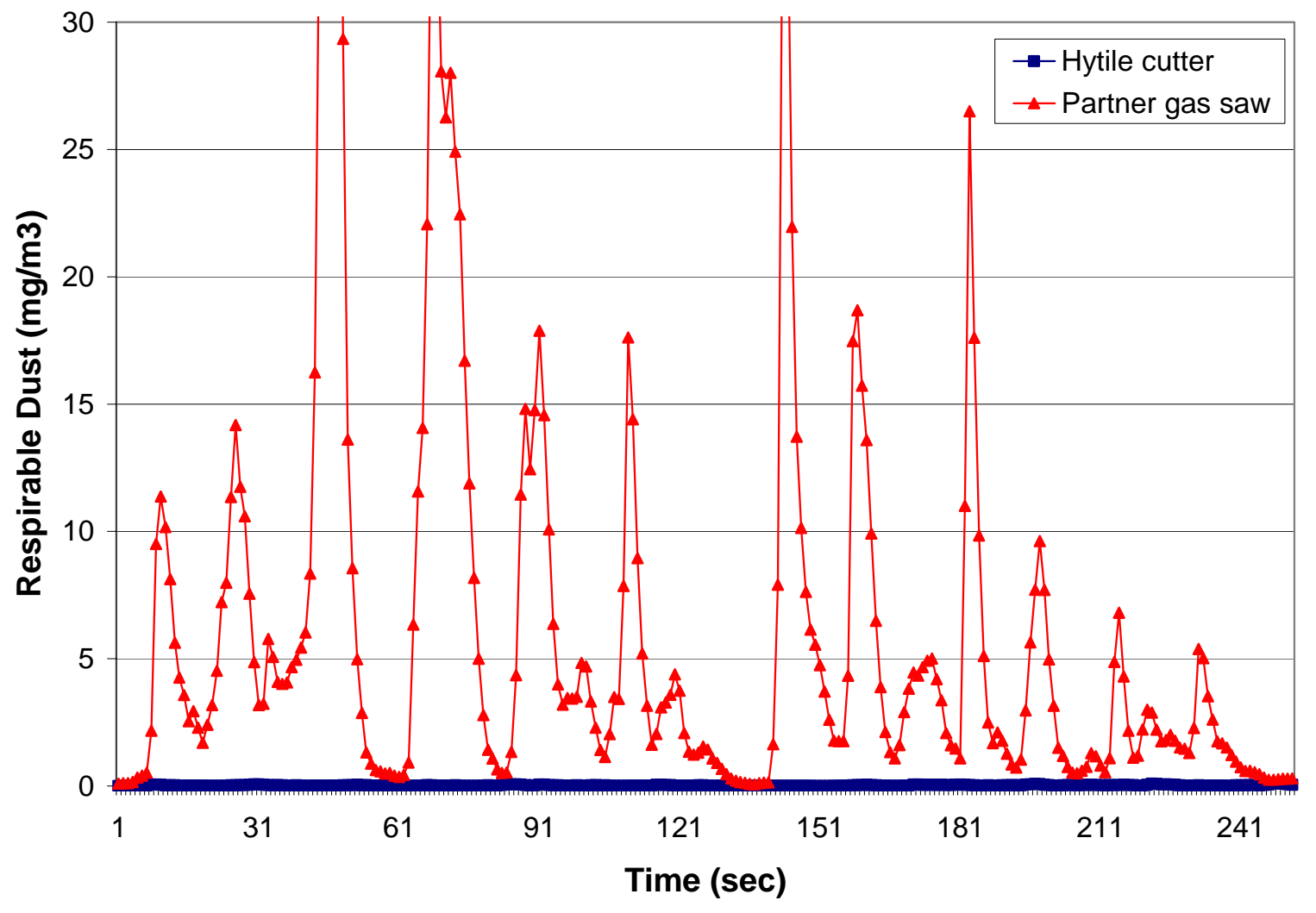

Figure 5. Direct Reading Results--Hytile Cutter versus Partner Gas

Saw 


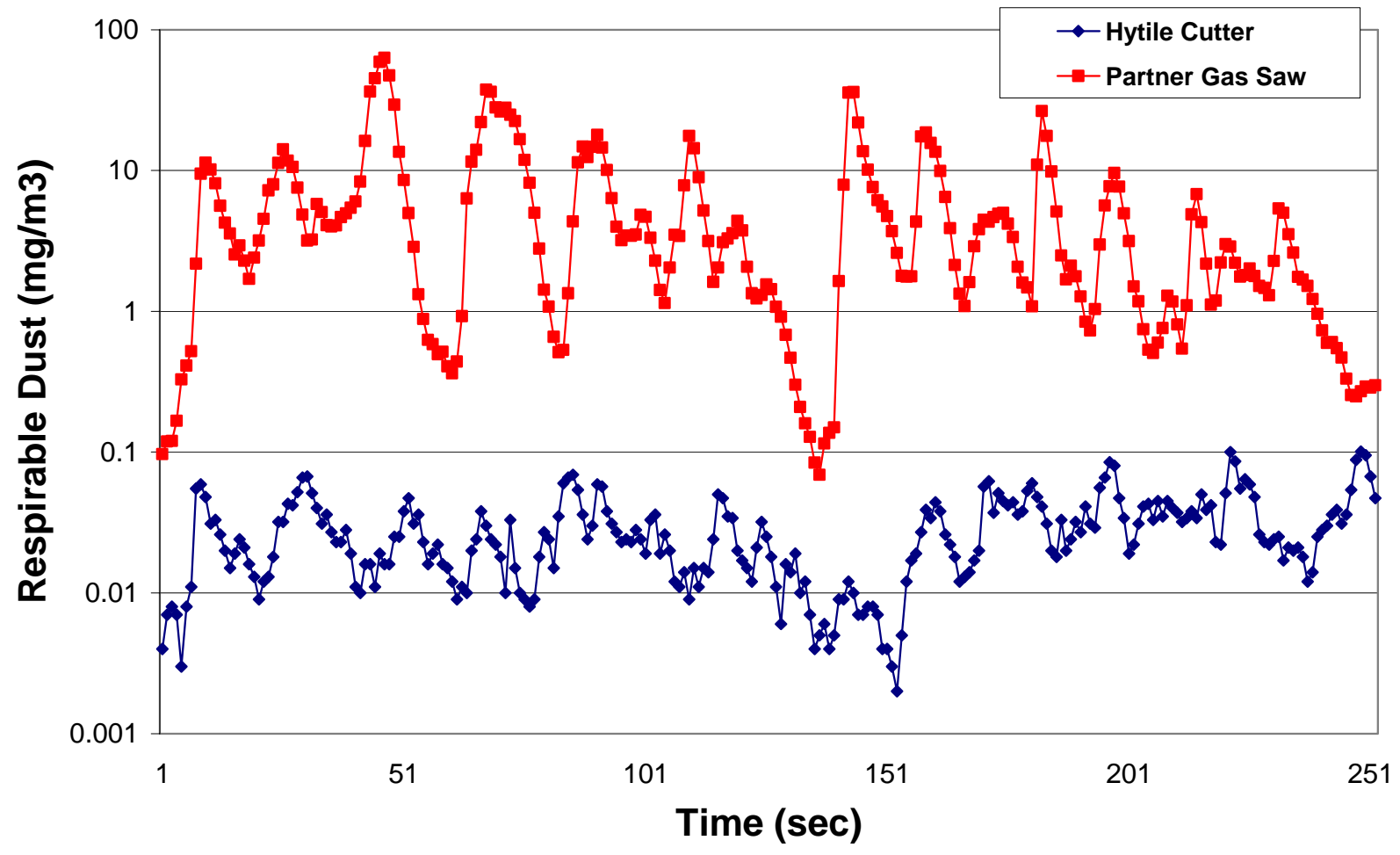

Figure 6. Direct Reading Results--Hytile Cutter versus Partner Gas Saw (log scale) 


\section{APPENDIX A Table A-1}

\begin{tabular}{|c|c|c|c|c|c|c|c|c|c|c|c|c|c|c|c|c|c|}
\hline \multirow{4}{*}{\begin{tabular}{|l|} 
DATE \\
$8 / 18 / 2005$ \\
\end{tabular}} & \multirow{4}{*}{\begin{tabular}{|l|}
$\begin{array}{l}\text { SAMPLE } \\
\text { LOCATION }\end{array}$ \\
outside south \\
\end{tabular}} & \multirow{4}{*}{\begin{tabular}{|l|} 
WORKER \\
Roofer 1 \\
\end{tabular}} & \multirow{4}{*}{\begin{tabular}{|l|} 
PROCESS \\
tile cutting \\
\end{tabular}} & \multirow{4}{*}{\begin{tabular}{|l} 
SAWICUTTER \\
Hytile-5;Bosch-5
\end{tabular}} & \multirow{4}{*}{$\begin{array}{c}\begin{array}{c}\text { Field } \\
\text { Sample\# }\end{array} \\
\text { AD5-540 } \\
\end{array}$} & \multirow{4}{*}{\begin{tabular}{|c|}
$\begin{array}{c}\text { Sample } \\
\text { Time } \\
\text { (min) }\end{array}$ \\
10 \\
\end{tabular}} & \multirow{4}{*}{\begin{tabular}{|c|}
$\begin{array}{l}\text { Flow } \\
\text { Rate } \\
\text { (Ipm) }\end{array}$ \\
2.22 \\
\end{tabular}} & \multirow{4}{*}{\begin{tabular}{|c|}
$\begin{array}{c}\text { Sample } \\
\text { Volume } \\
\text { (liters) }\end{array}$ \\
22.2 \\
\end{tabular}} & \multirow{3}{*}{\multicolumn{2}{|c|}{$\begin{array}{l}\text { Respirable Dust } \\
\text { Filter ug/sample }\end{array}$}} & \multirow{2}{*}{\multicolumn{3}{|c|}{$\begin{array}{l}\text { Respirable Dust } \\
\text { Concentration }\end{array}$}} & \multicolumn{4}{|c|}{ Silica Quartz } \\
\hline & & & & & & & & & & & & & & \multirow{2}{*}{\multicolumn{2}{|c|}{$\begin{array}{l}\text { Filter ugl } \\
\text { sample }\end{array}$}} & \multirow{2}{*}{\multicolumn{2}{|c|}{$\begin{array}{l}\text { Concentration } \\
\mathrm{mg} / \mathrm{m}^{3}\end{array}$}} \\
\hline & & & & & & & & & & & \multirow{2}{*}{\begin{tabular}{|c|}
$\mathrm{mg} / \mathrm{m}^{3}$ \\
0.6 \\
\end{tabular}} & \multicolumn{2}{|c|}{ mppcf* } & & & & \\
\hline & & & & & & & & & 14.1 & ND & & 6.0 & ND & & & & \\
\hline $8 / 18 / 2005$ & outside south & Roofer 1 & tile cutting & Hytile & AD5-558 & 5 & 4.19 & 21.0 & 14.1 & ND & 0.7 & 7.0 & ND & & & & \\
\hline $8 / 18 / 2005$ & outside south & Roofer 1 & tile cutting & Bosch & AD5-519 & 3 & 4.19 & 12.6 & 14.1 & ND & 1.1 & 11.0 & ND & & & & \\
\hline $8 / 19 / 2005$ & roof mock-up & Roofer 2 & s-tile cutting & Hytile & AD5-527 & 5.5 & 4.2 & 23.1 & 14.1 & ND & 0.6 & 6.1 & ND & 10 & ND & 0.31 & ND \\
\hline $8 / 19 / 2005$ & roof mock-up & Roofer 2 & f-tile cutting & Hytile & AD5-530 & 5.7 & 4.2 & 23.9 & 14.1 & ND & 0.6 & 5.9 & ND & 10 & ND & 0.30 & ND \\
\hline $8 / 19 / 2005$ & roof mock-up & Roofer 2 & tile cutting & Hytile & AD5-533 & 11.2 & 2.2 & 24.6 & 14.1 & $\mathrm{ND}$ & 0.6 & 5.7 & ND & 10 & ND & 0.29 & ND \\
\hline $8 / 19 / 2005$ & roof mock-up & Roofer 3 & s-tile cutting & Partner-Gaso & AD5-525 & 5.8 & 4.2 & 24.4 & 87.0 & & 3.6 & 35.7 & & 10 & & 0.41 & \\
\hline $8 / 19 / 2005$ & roof mock-up & Roofer 3 & f-tile cutting & Partner-Gaso & AD5-517 & 5.25 & 4.2 & 22.1 & 120.0 & & 5.4 & 54.4 & & 10 & & .0 .45 & \\
\hline $8 / 19 / 2005$ & roof mock-up & Roofer 3 & tile cutting & Partner-Gaso & AD5-528 & 11.1 & 2.2 & 24.4 & 89.0 & & 3.6 & 36.4 & & 10 & & 0.41 & \\
\hline $8 / 19 / 2005$ & roof mock-up & Roofer 2 & f-tile cutting & Hytile & AD5-521 & 5.5 & 4.2 & 23.1 & 14.1 & ND & 0.6 & 6.1 & ND & 10 & $\mathrm{ND}$ & 0.31 & ND \\
\hline $8 / 19 / 2005$ & roof mock-up & Roofer 2 & f-tile cutting & Hytile & AD5-526 & 5.3 & 4.2 & 22.3 & 14.1 & ND & 0.6 & 6.4 & ND & 10 & ND & 0.32 & ND \\
\hline $8 / 19 / 2005$ & roof mock-up & Roofer 2 & f-tile cutting & Hytile & AD5-522 & 10.8 & 2.2 & 23.8 & 14.1 & ND & 0.6 & 6.0 & ND & 10 & ND & 0.30 & ND \\
\hline $8 / 19 / 2005$ & roof mock-up & Roofer 4 & f-tile cutting & Partner-Gaso & AD5-535 & 4 & 4.2 & 16.8 & 53.0 & & 3.2 & 31.5 & & 10 & ND & 0.42 & ND \\
\hline \begin{tabular}{|l|}
$8 / 19 / 2005$ \\
\end{tabular} & roof mock-up & Roofer 4 & f-tile cutting & Partner-Gaso & AD5-512 & 4 & 2.2 & 8.8 & 14.1 & ND & 1.6 & 16.1 & ND & 10 & $\mathrm{ND}$ & 0.80 & ND \\
\hline
\end{tabular}

*mppcf=million particles per cubic foot 